\author{
Nobuya Mine • Kouichi Bando • Yoshihito Utada \\ Hisaki Nagai · Tsutomu Araki • Mitsuru Emi
}

\title{
Two single nucleotide polymorphisms of the hSNF5/INI1 gene
}

\begin{abstract}
We found two single nucleotide polymorphisms at the hSNF5/INI1 gene located on 22q11.2, encoding a member of the chromatin-remodelling SWI/SNF multiprotein complexes. A guanine/adenine polymorphism at codon 299 in exon 7, and another guanine/adenine polymorphism at $39 \mathrm{bp}$ upstream of exon 9 were identified. As the gene was recently identified as a tumor suppressor gene for malignant rhabdoid tumor, this polymorphism may be useful for the genetic study of susceptibility for human malignancies of various tissue origins.
\end{abstract}

Key words $h S N F 5 / I N I 1$ gene $\cdot$ Single nucleotide polymorphism · Malignant rhabdoid tumor · Chromosome 22q11.2 . Tumor suppressor gene

\section{Introduction}

The $h S N F 5 / I N I 1$ gene encodes a member of the chromatinremodelling SWI/SNF multiprotein complexes and is located at 22q11.2 (Kwon et al. 1994). Recently, inactivation of both alleles of the gene was identified in malignant rhabdoid tumors (MRTs), suggesting that loss-of-function mutations of the hSNF5/INII gene contributed to the oncogenesis of this type of tumor (Versteege et al. 1998). During screening of the entire coding region of the gene for sequence variations by polymerase chain reaction-singlestrand conformation polymorphism (PCR-SSCP) analysis, we identified two single nucleotide polymorphisms in the hSNF5/INI1 gene in a Japanese population.

N. Mine $\cdot$ K. Bando $\cdot$ Y. Utada $\cdot$ H. Nagai $\cdot$ M. Emi $(\bowtie)$

Department of Molecular Biology, Institute of Gerontology, Nippon Medical School, 1-396 Kosugi-cho, Nakahara-ku, Kawasaki 211-8533, Japan

Tel. +81-44-733-5230; Fax +81-44-733-5192

e-mail:memi@nms.ac.jp

N. Mine $\cdot$ T. Araki

Department of Obstetrics and Gynecology, Nippon Medical School,

Tokyo, Japan

\section{Source/Detection of polymorphisms}

In 192 Japanese individuals, all nine exons encoding the entire coding sequence of the $h S N F 5 / I N I$ gene were screened by PCR-SSCP analysis for single nucleotide variations of the gene. PCR-SSCP was carried out following procedures described previously (Hirayama et al. 1998). Variant SSCP bands were identified in the PCR products of exon 7 and exon 9. These variants were subcloned and sequenced as described previously (Tsukamoto et al. 1998). A G/A silent substitution at the third nucleotide of codon 299 in exon 7, and another G/A substitution at 39 bp upstream of exon 9 were identified (data not shown).

PCR primers

The PCR primers used were:

Forward (exon7-1) 5'-GCAAAAGCTCTAACTTGTGTC-3' Reverse (exon7-1) 5'-ATGCTGTATGCGATGGTGGT-3'

Forward (exon9) 5'-TACACTTGGCTGCCCTGTAG-3' Reverse (exon9) 5'-GCCCAATCTTCTGAGATGC-3'

\section{PCR conditions}

Each PCR was performed in a volume of $10 \mu$ containing 20 ng genomic DNA, in a $10-\mu$ l solution containing $10 \mathrm{mM}$ Tris- $\mathrm{HCl}$ ( $\mathrm{pH}$ 8.4), $50 \mathrm{mM} \mathrm{KCl}, 1.5 \mathrm{mM} \mathrm{MgCl}_{2}, 0.01 \%$ gelatin, $200 \mu \mathrm{M}$ each of dNTP, $2.5 \mathrm{pmol}$ of each primer, and 0.25 units of Taq polymerase. Each of $35 \mathrm{PCR}$ cycles consisted of $30 \mathrm{~s}$ at $94^{\circ} \mathrm{C}, 30 \mathrm{~s}$ at $60^{\circ} \mathrm{C}$, and $30 \mathrm{~s}$ at $72^{\circ} \mathrm{C}$ (Watanabe et al. 1998).

Allele-specific oligonucleotide (ASO) hybridization analysis. Hybridization to allele-specific oligonucleotides for each variable sequence in exon 7 or exon 9 was carried out as follows. The PCR products $(3-\mu \mathrm{l})$ were blotted on a Biodyne (Port Washington, NY, USA) transfer membrane. Oligonucleotide specific for the $G$ allele (5'- 
CTGTGCTCGGAGCTGGG-3') or the A allele (5'CTGTGCTCAGAGCTGGG-3') for exon 7 variations; or the $\mathrm{G}$ allele (5'-CAGGCTGGGAGCTGGCC-3') or the A allele (5'-CAGGCTGGAAGCTGGCC-3') for exon 9 variations was end-labeled with $\left[\gamma^{32} \mathrm{P}\right] \mathrm{ATP}$, using 10 units of $\mathrm{T} 4$ polynucleotide kinase. The membranes were hybridized in $6 \times$ sodium saline citrate (SSC), $2 \times$ Denhardt's, $0.5 \%$ sodium dodecylsulfate (SDS), and $50 \mathrm{mM}$ Tris-Hcl (pH7.5) overnight at $42^{\circ} \mathrm{C}$, and washed in $6 \times \mathrm{SSC}$ at $45^{\circ} \mathrm{C}$ for $10 \mathrm{~min}$. Membranes were blotted and exposed to X-ray film at $-80^{\circ} \mathrm{C}$

Allele frequency. A total of 192 Japanese individuals were genotyped for sequence variations of exon 7 and exon 9 . Allele frequencies of exon 7 were: $G$ allele 0.94 , A allele 0.06. Allele frequencies of exon 9 were: $\mathrm{G}$ allele 0.89 , A allele 0.11. Both polymorphisms were not in linkage disequibilibrum, and combined heterozygosity was 0.17 .

Mendelian inheritance. Codominant inheritance was observed in two two-generation families.

Chromosomal localization. The human SNF5/INI1 gene was assigned to human chromosome 22q11.2 (Versteege et al. 1998).
Other comments. No other variant of the hSNF5/INI gene, germline or somatic, was detected in 96 cases of breast cancer, 96 cases of hepatocellular carcinoma, or 48 cases of uterine corpus cancers during screening by PCR-SSCP analysis.

Acknowledgments This work was supported in part by a Research Grant for Cancer Research from the Ministry of Health and Welfare of Japan, and by a Research Grant for Cancer Research from the Ministry of Education, Science, Sports, and Culture of Japan.

\section{References}

Hirayama T, Yamaki E, Hara A, Tsuji M, Hashimoto K, Yamamoto M, Emi M (1998) Five familial hypercholesterolemic kindreds in Japan with novel mutation of the LDL receptor gene. J Hum Genet 43:250-254

Kwon H, Imbalzano AN, Khavari PA, Kingston RE, Green MR (1994) Nucleosome disruption and enhancement of activator binding by a human SW1/SNF complex. Nature 370:477-481

Tsukamoto K, Haruta K, Shiba T, Emi M (1998) Isolation and mapping of a polymorphic CA repeat sequence at the human interleukin 6 locus. J Hum Genet 43:71-72

Versteege I, Sevenet N, Lange J, Rousseau-Merck MF, Ambros P, Handgretinger R, Aurias A, Delattre o (1998) Truncating mutations of hSNF5/INI1 in aggressive paediatric cancer. Nature 394:203-206

Watanabe I, Tsukamoto K, Shiba T, Emi M (1998) Isolation and radiation hybrid mapping of dinucleotide repeat polymorphism at the human matrix Gla protein (MGP) locus. J Hum Genet 43:75-76 